\title{
Analisis Tingkat Pembelian Konsumen dengan Algoritma Apriori
}

\author{
Analysis of Consumer Purchases with the Apriori's Algorithm \\ Ismasari*1, Maulida Ramadhan $^{2}$, Wahyu Hadikristanto ${ }^{3}$ \\ ${ }^{1,2,3}$ Program Studi Teknik Informatika, Fakultas Teknik, Universitas Pelita Bangsa Bekasi \\ e-mail: *1 ismasari.n@ pelitabangsa.ac.id, ${ }^{2}$ maulidiaramadhan@gmail.com, \\ ${ }^{3}$ wahyu.hadikristanto@ pelitabangsa.ac.id
}

\begin{abstract}
Abstrak
Saat ini data mining telah diimplementasikan ke berbagai bidang salah satu diantaranya adalah pada bidang bisnis atau perdagangan yang dapat membantu para pebisnis dalam kebijakan pengambilan keputusan terhadap apa yang berhubungan dengan persediaan barang. Misalnya pentingnya sistem persediaan barang di suatu Toko dan jenis barang apa yang menjadi prioritas utama yang harus di stok untuk mengantisipasi kekosongan barang. Karena minimnya stok barang dapat berpengaruh pada pelayanan konsumen dan pendapatan Toko. Metode yang sering digunakan untuk menganalisa pola pembelian pelanggan adalah metode asosiasi atau association rule mining. Association rule mining adalah suatu metode untuk mencari pola hubungan antar satu atau lebih itemset yang ada dalam suatu dataset. Algoritma yang paling popular dalam mencari pola hubungan item set adalah algoritma apriori atau sering disebut dengan market basket analysis. Proses yang dilakukan dalam penelitian ini menggunakan tools Rapid Miner untuk mengolah data dengan algoritma apriori, dari pengujian yang dilakukan dengan parameter yang telah ditentukan yaitu minimum support $70 \%$ dan minimum confidence $80 \%$ menghasilkan 4 aturan asosiasi dengan nilai confidance 100\% yaitu kombinasi item aqua $600 \mathrm{ml}$ fulloblasto caramel cruncy chocolat - yupi 500 semua rasa - beng beng 25g. Dengan pencarian pola menggunakan algoritma apriori ini diharapkan informasi yang dihasilkan dapat meningkatakan strategi penjualan selanjutnya
\end{abstract}

Kata kunci-tingkat pembelian, persediaan barang, algoritma apriori, data mining

\begin{abstract}
Data Mining has been implemented in various fields, including business or trade, education and telecommunications. In the field of business, for example, the results of implementing data mining can help business people in making policy decisions regarding what is related to inventory. For example the importance of the inventory system in a store and what types of goods are the main priority that must be in stock to anticipate the emptiness of goods. Due to the lack of stock of goodscan affect customer service and store income. The method often used to analyze customer purchasing patterns is the association rule mining method. Association rule mining is a method for finding patterns of relationships between one or more itemset that is in a dataset. The most popular algorithm in finding patterns of itemset relationships is a priori algorithm or often called market basket analysis. The process carried out in this study uses RepidMiner tools to process data with a priori algorithms, from testing conducted with mredetermined parameters namely $70 \%$ minimum support and $80 \%$ minimum confidence resulting in 4 association rules with $100 \%$ confidence value ie a combination of AQUA items 600ML-FULLOBLASTO CARAMEL CRUNCY CHOCOLAT-YUPI 500 ALL FLAVOURS BENGBENG 25G. By searching for patterns using a priori algorithm, it is expected that the information generated can improve subsequent sales strategies.
\end{abstract} Keywords—purchase rate, inventory, a priory algorithm, data mining

\section{PENDAHULUAN}

Seiring dengan pertumbuhan bisnis di era globalisasi dan kemajuan di bidang teknologi informasi yang sangat cepat memberikan pengaruh yang sangat besar dalam bidang produk ataupun jasa. Hal ini juga membawa suatu perubahan besar dalam tingkat persaingan

Informasi Artikel:

Submitted: Juni 2020, Accepted: Agustus 2020, Published: November 2020

ISSN: 2685-4902 (media online), Website: http://jurnal.umus.ac.id/index.php/intech 
perusahaan, sehingga perusahaan dan pelaku-pelaku bisnis harus menciptakan berbagai solusi untuk bisa bertahan. Saat ini banyak sekali masalah dalam mengikuti perkembangan teknologi yang ada di zaman sekarang, terutama di dalam dunia perdagangan di mana semua pihak dituntut untuk memenuhi semua yang bersifat proses, karena proses yang lama masih belum bisa memenuhi pesatnya perkembangan teknologi di zaman sekarang, oleh karena itu banyak sekali peneliti yang mencoba untuk merubah pola-pola proses yang ada saat inti terutama di bidang perdagangan. Toko Surya Mart merupakan toko yang menjual kebutuhan bahan-bahan pokok dan kebutuhan barang rumah tangga, Toko Surya Mart selalu berusaha memberikan pelayanan terbaik agar kepuasan bagi konsumen dapat terwujud dengan menyediakan produk yang berkualitas. Dikarenakan badan usaha ini masih baru berjalan dan banyak sekali pesaing yang harus dihadapi, Toko Surya Mart dituntut untuk selalu memikirkan strategi apa yang akan digunakan untuk meningkatkan penjualan barang. Salah satunya dengan memanfaatkan data transaksi. Data transaksi ini dapat diolah menjadi informasi yang menguntungkan bagi toko itu sendiri, dalam menyimpan jumlah record transaksi penjualan yang memiliki data yang sangat besar, sehingga menyebabkan jumlah data terus menerus bertambah setiap harinya.

Selama ini transaksi yang terjadi hanya dibiarkan menumpuk dan menjadi gudang data. Tidak ada analisis terhadap data penjualan mengenai pola pembelian pelanggan yang seharusnya, karena data tersebut dapat memberikan informasi atau pengetahuan yang bermanfaat jika diolah dengan baik. Salah satu usaha untuk menggali informasi atau nilai tambah dari suatu gudang data yang sering disebut dengan data mining[1]. Metode yang sering digunakan untuk menganalisa pola pembelian pelanggan adalah metode asosiasi atau association rule mining. Association rule mining adalah suatu metode untuk mencari pola hubungan antar satu atau lebih itemset yang ada dalam suatu dataset[2]. Algoritma yang paling popular dalam mencari pola hubungan itemset adalah algoritma apriori atau sering disebut dengan market basket analysis. Dengan algoritma apriori ini, maka pimpinan Toko Surya Mart dapat mengetahui pola pembelian konsumennya. Pada penelitian ini, penulis memilih algoritma apriori karena kelebihannya yang dapat mengurangi kandidat yang harus dihitung supportnya sehingga memiliki performa yang jauh lebih baik[3].

Beberapa penelitian terkait yang pernah dilakukan mengenai penerapan algoritma apriori adalah mengenai penerapan apriori dan association rule terhadap transaksi pembelian produk kepada konsumen berdasarkan nilai support minimum sebesar $85 \%$ dan nilai confidence minimum sebesar $90 \%$ yang diterapkan sebagai dasar pengambilan keputusan perusahaan pada area pemasaran[4]. Selain itu algoritma apriori juga dapat membantu mengembangkan strategi pemasaran untuk memasarkan produk lain dengan menganalisa kelebihan dari nilai jual produk yang paling laris terjual. Hal tersebut dapat dilihat dari hasil penelitian yang menunjukkan bahwa penjualan produk pipa paling banyak terjual pada CV. Gaskindo Sentosa, dengan melihat produk yang memenuhi minimal support dan minimal confidence [5]. Dari aturan asosiasi pada perusahaan retail X, diketahui bahwa algoritma apriori dapat digunakan untuk mencari nama barang yang paling sering dibeli oleh konsumen dengan kemunculan nama barang tersebut pada transaksi penjualan yang dilakukan[6]. Selain untuk mengetahui jenis barang yang paling dicari, apriori juga dapat digunakan untuk pengendalian terhadap kualitas suatu produk pada PT Juahn Indonesia Bekasi melalui 17 rules dan 4 itemset defect yang sering muncul pada proses injection[7]. Apriori juga pernah digunakan untuk mengetahui pola belanja konsumen yang selanjutnya akan digunakan untuk Analisa pola belanja konsumen sehingga Starcomp Jogja dapat melakukan promo atau diskon beberapa produknya[8]. Apriori juga pernah dibandingan dengan FP-Growth dalam menentukan daerah strategis pengenalan kampus, dimana menurut penelitian didapatkan bahwa FP-Growth mendapatkan hasil yang lebih baik dari sisi waktu proses, frequent itemset serta nilai confidence[9] 


\section{METODE PENELITIAN}

\section{Kerangka pemikiran}

Pada penelitian ini, objek yang akan diambil adalah di Toko Surya Mart (Bogor) dengan mengambil data transaksi penjualan barang periode bulan April sampai dengan Desember Tahun 2019. Penelitian ini menggunakan pendekatan secara prototype melalui simulasi alur software yang akan dibuat untuk mengetahui gambaran software yang akan dibuat[10].

Untuk memudahkan proses pembuatan sistem, maka penulis membuat suatu kerangka pemikiran dari proses pengumpulan data sampai dengan penarikan kesimpulan. Pada tahapan pengumpulan data, penulis melakukan tahapan wawancara untuk menggali data atau memperoleh informasi yang berhubungan dengan penelitian dengan pihak terkait yang berkompeten[11]. Selain wawancara, penulis juga melakukan pengamatan (observasi) terhadap objek data dengan tujuan mendapatkan korelasi antara persediaan barang dengan kebutuhan si pelanggan agar tidak terjadi kekosongan barang. Selanjutnya akan dilakukan pengolahan data melalui pendekatan algoritma apriori untuk pengolahan data barang, adapun langkah-langkah yang dilakukan untuk pembentukan model data mining dengan algoritma apriori adalah sebagai berikut:

a. Menentukan data yang akan diproses. Data yang diuji adalah data transaksi penjualan terhadap kebutuhan bahan pokok dan kebutuhan barang rumah tangga pada bulan April sampai dengan Desember 2019

b. Menentukan minimal support dan minimal confidence.

Selanjutnya untuk mengetahu hasil perhitungan yang dianalisa sudah bekerja dengan baik dan tidak ada kesalahan, maka akan dilakukan pengujian dengan menggunakan tools Rapid Miner untuk memastikan apakah hasil perhitungan manual dan dengan Rapid Miner sama atau tidak. Selanjutnya akan dilakukan evaluasi dengan cara mengamati dan menganalisa hasil dari algoritma yang digunakan berdasarkan pengujian yang telah dilakukan. Hasil yang di peroleh dari penelitian ini adalah penentuan pola kombinasi itemset frekuensi tinggi yaitu yang memperoleh support dan confidence tertinggi. Gambaran mengenai kerangka berpikir yang dilakukan penulis selanjutnya terdapat pada Gambar 1.

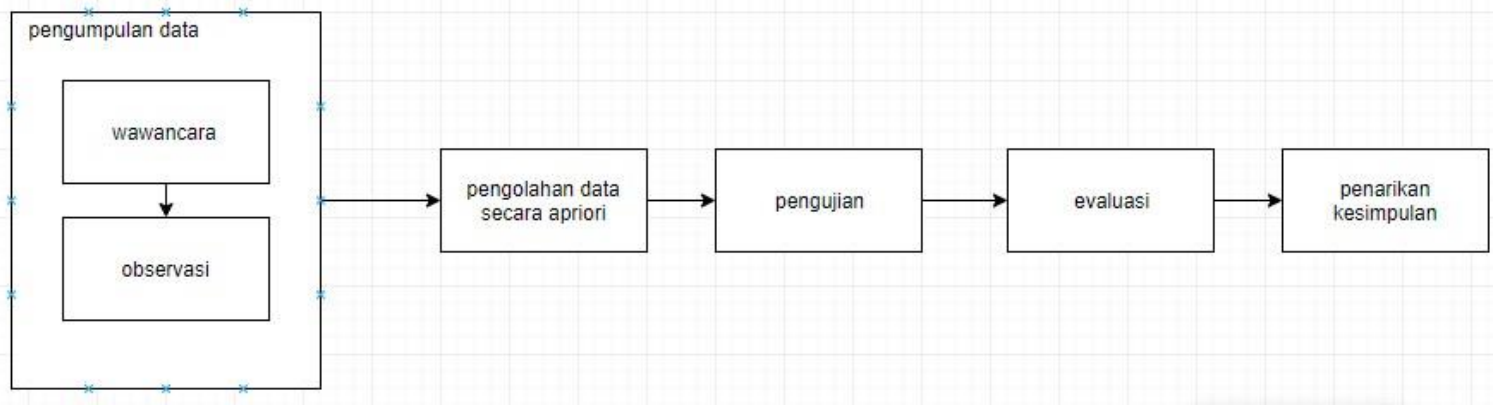

Gambar 1. Kerangka berfikir

\section{Association rule mining}

Association rule mining atau analisis asosiasi merupakan salah satu Teknik data mining dalam menemukan aturan asosiasi antara kombinasi item[12]. Secara umum association rule memiliki bentuk:

$$
\text { LHS }=>\text { RHS }
$$

Dimana :

LHS dan RHS adalah himpunan item [12]

Adapun aturan asosiasi dapat ditulis dengan:[13]

$$
\{\mathrm{A}, \mathrm{B}\}=>\{\mathrm{C}\}(\text { Support }=10 \% \text {, confidance }=50 \%)
$$


Beberapa istilah yang digunakan dalam datamining adalah:

a. Support

Support merupakan suatu prosentase kombinasi item dalam database, dimana jika item A dan item B maka supportnya adalah transaksi dalam database yang mengandung A dan B [14].

b. Confidance

Sedangkan confidance dari suatu association rule adalah suatu ukuran ketepatan rule yang merupakan representasi dalam suatu database yang mengandung A dan mengandung $\mathrm{B}[12]$.

c. Minimum support

Merupakan parameter yang digunakan sebagai batasan frekuensi kejadian atau support count yang harus dipenuhi suatu kelompok data untuk dapat dijadikan aturan[14]

d. Minimum confidance

Merupakan parameter yang mendefinisikan minimum level dari confidence yang harus dipenuhi oleh aturan yang berkualitas [14]

e. Itemset

Merupakan suatu kelompok produk

f. Kandidat set

Merupakan suatu itemset - itemset yang akan dihitung support count-nya. [14]

g. Frequanry itemset

Merupakan suatu itemset yang sering terjadi, atau itemset-itemset yang sudah melewati batas minimum support yang telah ditentukan [13]

\section{Algoritma Apriori}

Algoritma apriori adalah salah satu algoritma asosiasi pada data mining, dimana aturan asosiasi yang terdapat didalamnya sering disebut dengan Market Based Analysis (MBA)[15]. Secara umum untuk melakukan proses perhitungan apriori dibutuhkan candidate frequent itemset untuk melakukan iterasi ke-k terhadap struktur data yang diolah serta frequent itemset untuk menyimpannya [15]. Adapun langkah-langkah algoritma apriori adalah sebagai berikut[16]:

a. Hitung nilai confidence, dengan cara:

(1). Cari frekuensi tertinggi sebuah item dengan rumus 1

$$
\text { support }(A)=\frac{j u m l a h \text { transaksi mengandung } A}{\text { total transaksi }}
$$

(2). Cari frekuensi tertinggi dua buah item dengan rumus 2

$$
\text { support }(A, B)=\frac{\text { jumlah transaksi mengandung } A \text { dan } B}{\text { total transaksi }}
$$

b. Setelah mendapatkan nilai confidence, maka bentuk aturan asosiatif melalui algoritma apriori dengan cara:

(1). Temukan assosition rule

(2). Buatlah table tabularnya

(3). Buatlah 2 kombinasi dari 2 item dataset

(4). Pilih frekuensi yang lebih besar atau sama dengan batas minimum yang sudah ditentukan

(5). Buatlah 2 kombinasi kembali dari 3 item dataset 


\section{HASIL DAN PEMBAHASAN}

Tahapan awal yang dilakukan pada penelitian ini adalah mempersiapkan data, data yang akan diolah dalam penelitian ini yaitu data penjualan dari Toko Surya Mart bulan April sampai dengan Desember 2019. Sebagai perhitungan tentang algoritma apriori dengan metode asosiasi penulis mengambil data yang akan diolah sebagai contoh yaitu sebanyak 30 data penjualan seperti pada Tabel 1.

\section{Tabel 1. Data transaksi penjualan}

\begin{tabular}{clc} 
No & \multicolumn{1}{c}{ Nama barang } & Jumlah \\
\hline 1 & Kenko batik gel & 3 \\
\hline 2 & Aqua & 8 \\
\hline 3 & Deka wafer roll semua rasa & 6 \\
\hline 4 & Gery pasta coklat & 2 \\
\hline 5 & Cannonball cok & 6 \\
\hline 6 & Pars krupuk udang 15gr & 4 \\
\hline 7 & Sprite 390ml & 5 \\
\hline 8 & Gery cocolatos & 3 \\
\hline 9 & Waku-waku starwbery & 8 \\
\hline 10 & Fullo blasto caramel & $\ldots$ \\
\hline$\ldots$ & $\ldots$ & Top triple choco
\end{tabular}

Sebagai perhitungan tentang algoritma apriori dengan metode assosiasi penulis mengambil data yang akan diolah sebagai contoh yaitu 10 data penjualan barang. Penulis memberikan batasan nilai minimum support 0.7 atau sama dengan $70 \%$ dan confidence 0.8 atau sama dengan $80 \%$. Berdasarkan rumus (1) maka perhitungannya adalah:

support (Aksesoris) $=\frac{3}{10} \times 100 \%=30,00$

Semua perhitungan ini berlaku untuk semua nama barang yang tertera pada Tabel 1 . Rangkuman mengenai hasil perhitungan kandidat 1 item teradapat pada Tabel 2.

Table 2. Kandidate 1 item (c1)

\begin{tabular}{clcc}
\hline No & \multicolumn{1}{c}{ Item set } & Transaksi & Support $(\%)$ \\
\hline 1 & Kenko batik gel & $(3 / 10)^{*} 100$ & 30,00 \\
\hline 2 & Aqua & $(8 / 10)^{*} 100$ & 80,00 \\
\hline 3 & Deka wafer roll semua rasa & $(6 / 10)^{*} 100$ & 60,00 \\
\hline 4 & Gery pasta coklat & $(2 / 10)^{*} 100$ & 20,00 \\
\hline 5 & Cannonball cok & $(6 / 10) * 100$ & 60,00 \\
\hline 6 & Pars krupuk udang 15gr & $(4 / 10)^{*} 100$ & 40,00 \\
\hline 7 & Sprite 390ml & $(5 / 10) * 100$ & 50,00 \\
\hline 8 & Gery cocolatos & $(3 / 10) * 100$ & 30,00 \\
\hline 9 & Waku-waku starwbery & $(6 / 10) * 100$ & 60,00 \\
\hline 10 & Fullo blasto caramel & $(8 / 10) * 100$ & 80,00 \\
\hline$\ldots$ & $\ldots$ & $\ldots$ & $\ldots$ \\
\hline 30 & Top triple choco & $(4 / 10) * 100$ & 40,00 \\
\hline
\end{tabular}

Berdasarkan pembentukan itemset pada Tabel 2, dengan nilai minimum support $70 \%$, maka dapat diketahui yang memenuhi standart minimum support yaitu ada 6 itemset, yang selanjutnya dari 6 item tersebut kemudian akan dibentuk kombinasi 2 itemset. Itemset yang memenuhi standar minimum support terdapat pada Tabel 3. 
Table 3. Large 1-itemset (L1)

\begin{tabular}{clcc}
\hline No & \multicolumn{1}{c}{ Item set } & Transaksi & Support (\%) \\
\hline 1 & Aqua & 8 & 80,00 \\
\hline 2 & Fullo blasto caramel & 8 & 80,00 \\
\hline 3 & Yupi 500 semua rasa & 9 & 90,00 \\
\hline 4 & Beng beng 25gr & 9 & 90,00 \\
\hline 5 & Antangin permen & 80 & 80,00 \\
\hline 6 & Cheetos JB 15gr & 7 & 70,00 \\
\hline
\end{tabular}

Selanjutnya akan dihitung 2 item dengan jumlah minimum support $70 \%$ dengan rumus (2). Rangkuman hasil kandidat 2 itemset terangkum pada Tabel 4.

Table 4. kandidat 2-itemset

\begin{tabular}{clcc} 
No & \multicolumn{1}{c}{ Itemset } & Transaksi & Support (\%) \\
\hline 1 & Aqua, fullo blasto caramel & $(7 / 10) * 100$ & 70,00 \\
\hline 2 & Aqua, yuppi 500 semua rasa & $(8 / 10) * 100$ & 80,00 \\
\hline 3 & Aqua, beng-beng 25gr & $(8.10) * 100$ & 80,00 \\
\hline 4 & Aqua, antangin permen & $(7 / 10) * 100$ & 70,00 \\
\hline 5 & $\begin{array}{l}\text { Fullo blasto caramel, yupi semua } \\
\text { rasa }\end{array}$ & $(8 / 10) * 100$ & 80,00 \\
\hline 6 & $\begin{array}{l}\text { Fullo blasto caramel, beng-beng } \\
\text { 25gt }\end{array}$ & $(7 / 10) * 100$ & 70,00 \\
\hline 7 & Yupi semua rasa, beng-beng 25gr & $(8 / 10) * 100$ & 80,00 \\
\hline 8 & Yupi semua rasa, antangin permen & $(7 / 10) * 100$ & 70,00 \\
\hline 9 & Beng-beng 25gr, antangin permen & $(8 / 10) * 100$ & 80,00 \\
\hline
\end{tabular}

Kemudian dari 5 itemset yang masih memenuhi minimum support akan dibentuk 3 itemset proses pencarian 3 itemset tersebut terangkum pada Tabel 5.

Table 5. kandidat 4-itemset

\begin{tabular}{clcc}
\hline No & \multicolumn{1}{c}{ Itemset } & Transaksi & Support (\%) \\
\hline 1 & $\begin{array}{l}\text { Aqua, fullo blasto, yupi semua } \\
\text { rasa, beng-beng 25gr }\end{array}$ & $(7 / 10) * 100$ & 70,00 \\
\hline 2 & $\begin{array}{l}\text { Aqua, fullo blasto, yupi semua } \\
\text { rasa, antangin permen }\end{array}$ & $(6 / 10) * 100$ & 60,00 \\
\hline 3 & $\begin{array}{l}\text { Aqua, fullo blasto, beng-beng 25gt, } \\
\text { antangin permen }\end{array}$ & $(6 / 10) * 100$ & 60,00 \\
\hline
\end{tabular}

Kemudian dari 4 itemset yang masih memenuhi minimum support akan dibentuk 3 itemset proses pencarian 4 itemset tersebut terangkum pada Tabel 6.

Table 6. kandidat 4-itemset

\begin{tabular}{ccccc}
\hline No & \multicolumn{2}{c}{ Itemset } & Transaksi & Support (\%) \\
\hline 1 & $\begin{array}{l}\text { Aqua, fullo blasto, yupi } \\
\text { rasa, beng-beng 25gr }\end{array}$ & semua & $(7 / 10) * 100$ & 70,00 \\
\hline
\end{tabular}

Dalam kombinasi 4 itemset semua data belum bisa mencangkup minimum support $70 \%$, oleh karena itu iterasi dihentikan. Tabel 7 adalah seluruh Large itemset yang memenuhi minimum support.

Tabel 7. Seluruh large itemset hasil iterasi

\begin{tabular}{clcc}
\hline No & \multicolumn{1}{c}{ Item set } & Transaksi & $\begin{array}{c}\text { Support } \\
(\boldsymbol{\%})\end{array}$ \\
\hline 1 & Aqua, Fullo blasto caramel & 7 & $70,00 \%$ \\
\hline 2 & Aqua, Yupi 500 semua rasa & 8 & $80,00 \%$ \\
\hline
\end{tabular}




\begin{tabular}{rlll}
\hline 3 & Aqua, Yupi 500 semua rasa & 8 & $80,00 \%$ \\
\hline 4 & Aqua, Fullo blasto caramel, Yupi 500 semua & 7 & $70,00 \%$ \\
\hline 5 & Aqua, Fullo blasto caramel, Yupi 500 semua & 7 & $70,00 \%$ \\
\hline 6 & $\begin{array}{l}\text { Fullo blasto caramel, Yupi 500 semua rasa, Beng- } \\
\text { beng 25 g }\end{array}$ & 7 & $70,00 \%$ \\
\hline 7 & Aqua, Fullo blasto, Yupi 500 semua, Beng-beng 25 g & 7 & $70,00 \%$ \\
\hline
\end{tabular}

Dari seluruh itemset yang terbentuk, kemudian dilakukan pemisahan antara antecedent dengan consequent untuk menentukan seluruh kemungkinan asosiasi yang terbentuk adalah:

Aqua $=>$ Fullo blasto caramel

Kecenderungan konsumen yang membeli aqua juga akan juga akan membeli Fullo blasto caramel, namun bukan berarti konsumen yang membeli Fullo blasto caramel juga cenderung akan membeli Yupi 500 semua. Menurut posisi dalam aturan, aqua adalah analisis unit, atau bisa disebut antecedent (bagian jika), sedangkan Fullo blasto caramel adalah associated unit atau biasa disebut dengan consequent (bagian maka). Tabel 8 adalah itemset yang telah dilakukan pemisahan antara atancedent dengan consequent-nya.

Table 8. pemisahan antara antecedent dengan consequent

\begin{tabular}{clll}
\hline No & \multicolumn{1}{c}{ Antecedent } & \multicolumn{1}{c}{ Consequent } & Support (\%) \\
\hline 1 & Aqua & Fullo blasto & 70,00 \\
\hline 2 & Aqua & Yupi & 80,00 \\
\hline 3 & Aqua & Beng - beng & 80 \\
\hline 4 & Fullo blasto & Aqua & 70,00 \\
\hline 5 & Fullo blasto & Yupi 500 semua & 70,00 \\
\hline 6 & Fullo blasto & Beng-beng 25 g & 70,00 \\
\hline 7 & Yupi 500 semua & aqua & 80,00 \\
\hline 8 & Yupi 500 semua & Fullo blasto & 70,00 \\
\hline 9 & Yupi 500 semua & Beng-beng 25 g & 80,00 \\
\hline 10 & Beng-beng 25 g & Aqua & 80,00 \\
\hline 11 & Beng-beng 25 g & Aqua & 80,00 \\
\hline 12 & Beng-beng 25 g & Yupi 500 semua & 80,00 \\
\hline
\end{tabular}

Setelah pemisahan antecedent dan consequent terbentuk, langkah selanjutnya adalah menghitung confidence dari masing- masing item berdasarkan rumus (2).

Untuk:

Confidence Aqua $\rightarrow$ Fullo blasto

Maka akan dilakukan perhitungan:

support (Aqua, fullo blasto) $=\frac{7}{8} \times 100 \%=87,50$

Rangkuman mengenai hasil perhitungan confidence terdapat pada Tabel 9.

Table 9. Hasil perhitungan confidence

\begin{tabular}{cllccc}
\hline No & Antecement & \multicolumn{1}{c}{ Consequent } & Support (\%) & $\begin{array}{c}\text { Proses confidence } \\
(\boldsymbol{\%})\end{array}$ & $\begin{array}{c}\text { Confidence } \\
(\boldsymbol{\%})\end{array}$ \\
\hline 1 & Aqua & Fullo blasto & 70,00 & $(7 / 8)^{*} 100$ & 87,50 \\
\hline 2 & Aqua & Yupi 500 semua & 80,00 & $(8 / 8)^{*} 100$ & 100 \\
\hline 3 & Aqua & Beng-beng 25 g & 80,00 & $(8 / 8)^{*} 100$ & 100 \\
\hline 4 & Fullo blasto & Aqua & 70,00 & $(7 / 8)^{*} 100$ & 87,50 \\
\hline 5 & Fullo blasto & Yupi 500 semua & 70,00 & $(7 / 8)^{*} 100$ & 87,50 \\
\hline 6 & Fullo blasto & Beng-beng 25 g & 70,00 & $(7 / 8)^{*} 100$ & 87,50 \\
\hline 7 & Yupi 500 semua & Aqua & 80,00 & $(8 / 9)^{*} 100$ & 88,89 \\
\hline 8 & Yupi 500 semua & Fullo blasto & 70,00 & $(7 / 9)^{*} 100$ & 77,79 \\
\hline
\end{tabular}


ISSN: 2685-4902 (online)

\begin{tabular}{ccllll}
\hline 9 & Yupi 500 semua & Beng-beng 25 g & 80,00 & $(8 / 9)^{*} 100$ & 88,89 \\
\hline 10 & Beng-beng 25 g & Aqua & 80,00 & $(8 / 9) * 100$ & 88,89 \\
\hline 11 & Beng-beng 25 g & Fullo blasto & 70,00 & $(7 / 9) * 100$ & 77,79 \\
\hline 12 & Beng-beng 25 g & Yupi 500 semua & 80,00 & $(8 / 9) * 100$ & 88,89 \\
\hline
\end{tabular}

Nilai minimum confidence dalam penelitian ini ditentukan sebesar $80 \%$, maka itemset yang bernilai kurang dari $80 \%$ akan dihilangkan, Tabel 10 adalah itemset yang memenuhi minimum confidence.

Table 10. Itemset yang memenuhi minimum confidence

\begin{tabular}{cllccc}
\hline No & Antecement & \multicolumn{1}{c}{ Consequent } & Support $(\boldsymbol{\%})$ & $\begin{array}{c}\text { Proses confidence } \\
(\mathbf{\%})\end{array}$ & $\begin{array}{c}\text { Confidence } \\
(\mathbf{\%})\end{array}$ \\
\hline 1 & Aqua & Fullo blasto & 70,00 & $(7 / 8)^{*} 100$ & 87,50 \\
\hline 2 & Aqua & Yupi 500 semua & 80,00 & $(8 / 8)^{*} 100$ & 100 \\
\hline 3 & Aqua & Beng-beng 25 g & 80,00 & $(8 / 8)^{*} 100$ & 100 \\
\hline 4 & Fullo blasto & Aqua & 70,00 & $(7 / 8)^{*} 100$ & 87,50 \\
\hline 5 & Fullo blasto & Yupi 500 semua & 70,00 & $(7 / 8)^{*} 100$ & 87,50 \\
\hline 6 & Fullo blasto & Beng-beng 25 g & 70,00 & $(7 / 8)^{*} 100$ & 87,50 \\
\hline 7 & Yupi 500 semua & Aqua & 80,00 & $(8 / 9) * 100$ & 88,89 \\
\hline 9 & Yupi 500 semua & Beng-beng 25 g & 80,00 & $(8 / 9)^{*} 100$ & 88,89 \\
\hline 10 & Beng-beng 25 g & Aqua & 80,00 & $(8 / 9)^{*} 100$ & 88,89 \\
\hline 12 & Beng-beng 25 g & Yupi 500 semua & 80,00 & $(8 / 9)^{*} 100$ & 88,89 \\
\hline
\end{tabular}

Pada hasil penjualan pola perhitungan yang digunakan dengan Algoritma Apriori, terdapat pengaruh positif pada penjualan terhadap produk di Toko Surya Mart. Sehingga dari hasil tersebut dapat dilihat produk yang paling banyak terjual.

Dalam penelitian ini penulis menggunakan pengujian dengan tools Rapid Miner yang berguna untuk menenemukan pola-pola yang tidak diketahui sebelumnya pada hasil penjualan. Dimana pola perhitungan yang digunakan dengan Algoritma Apriori, terdapat pengaruh positif pada penjualan terhadap produk di Toko Surya Mart. Sehingga dari hasil tersebut dapat dilihat produk yang paling banyak terjual. Berdasarkan hasil pengujian diketahui bahwa association rule yang terbentuk pada Rapid Miner sama seperti perhitungan system hal tersebut terlihat pada Gambar 2 dan 3.

\begin{tabular}{|c|c|c|c|c|c|c|}
\hline Show rules matching & \multirow[t]{2}{*}{ No. } & \multirow{2}{*}{$\begin{array}{l}\text { Premises } \\
\text { FULLOBLASTO CARAMEL CRUNCY CHOCOLAT }\end{array}$} & \multirow{2}{*}{$\begin{array}{l}\text { Conclusion } \\
\text { BENG BENG } 25 G\end{array}$} & \multirow{2}{*}{$\begin{array}{l}\text { Support } \\
0.700\end{array}$} & \multirow{2}{*}{$\begin{array}{l}\text { Confidence } \\
0.875\end{array}$} & \multirow{2}{*}{$\begin{array}{l}\text { LaPlace } \\
0.944\end{array}$} \\
\hline all of these conclusions: & & & & & & \\
\hline \multirow{9}{*}{$\begin{array}{l}\text { BENG BENG } 256 \\
\text { YUPI } 500 \text { SEMUAARASA } \\
\text { AOUA 600ML } \\
\text { FULLOBLASTO CARAMEL CRUN.. }\end{array}$} & 4 & AQUA GOOML & FULLOBLASTO CARAMEL CRUNCY CHOCOLAT & 0.700 & 0.875 & 0.944 \\
\hline & 5 & FULLOELASTO CARAMEL CRUNCY CHOCOLAT & AQUA $600 M L$ & 0.700 & 0.875 & 0.944 \\
\hline & 6 & AQUA 600ML & BENG BENG 25G, FULLOELASTO CARAMEL CR... & 0.700 & 0.875 & 0.944 \\
\hline & 7 & FULLOBLASTO CARAMEL CRUNNCY CHOCOLAT & BENG BENG 25G, AOUA 600ML & 0.700 & 0.875 & 0.944 \\
\hline & 8 & YUPI 500 SEMUA RASA & FULLOELASTO CARAMEL CRUNVY CHOCOLAT & 0.800 & 0.889 & 0.947 \\
\hline & 9 & FULLOELASTO CARAMEL CRUNNCY CHOCOLAT & YUPI 500 SEMUA RASA & 0.800 & 1 & 1 \\
\hline & 10 & BENG BENG 25G, FULLOBLASTO CARAMEL CR. & AQUA 600ML & 0.700 & 1 & 1 \\
\hline & 11 & AQUA 600ML, FULLOELASTO CARAJIEL CRUNC. & BENG BENG $25 G$ & 0.700 & 1 & 1 \\
\hline & 12 & BENG BENG 25G, AQUA 600ML & FULLOBLASTO CARAMEL CRUNCY CHOCOLAT & 0.700 & $\infty$ & 1.700 \\
\hline
\end{tabular}

Gambar 2. Tampilan result data produk 


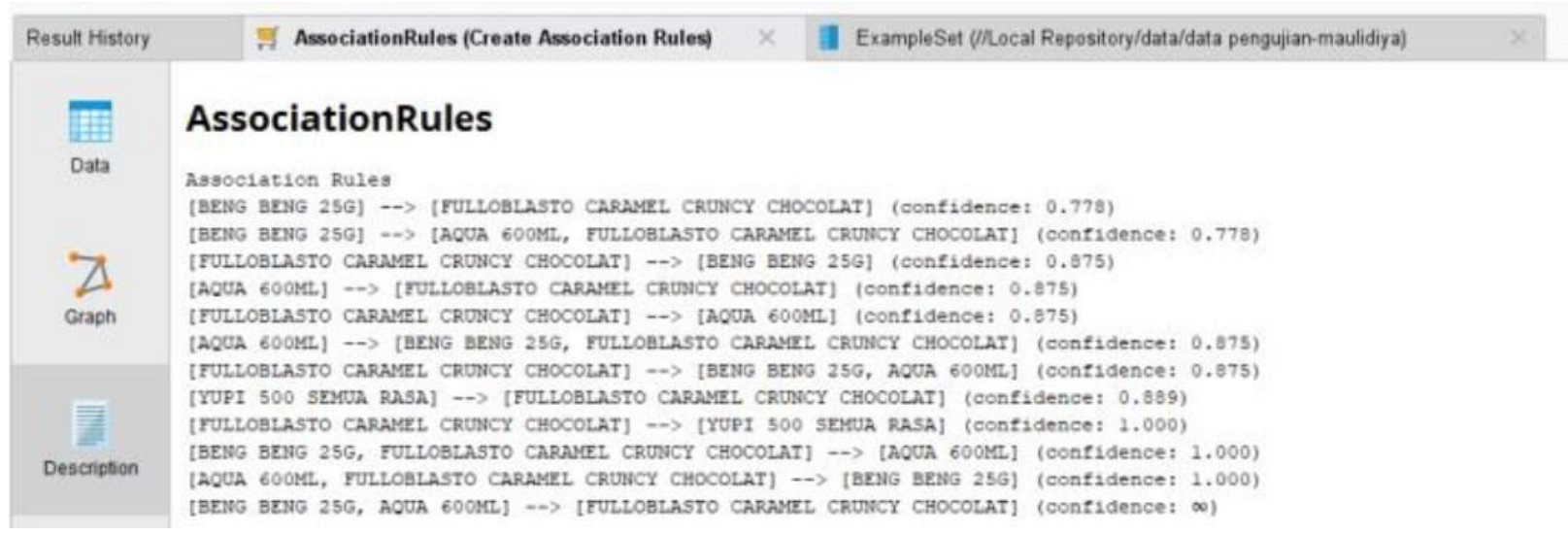

Gambar 3. Tampilan description association rules

\section{KESIMPULAN}

Dari hasil analisa dan pengujian yang telah dilakukan mengunakan data transaksi penjualan di Toko Surya Mart selama periode bulan April 2019, dengan merubah parameter minimum support dan minimum confidence menggunakan algoritma apriori dan aturan asosiasi. Terbentuk aturan asosiasi dengan nilai confidance $100 \%$ yaitu kombinasi item AQUA 600ML $\Rightarrow$ FULLOBLASTO CARAMEL CRUNCY CHOCOLAT $\Rightarrow$ YUPI 500 SEMUA RASA $\Rightarrow$ BENG BENG 25G. Maka dapat disimpulkan bahwa kombinasi menu item tersebut yang dapat menetukan stok barang untuk bulan selanjutnya.

\section{DAFTAR PUSTAKA}

[1] J. Han, M. Kamber, and J. Pei, Data Mining: Concepts and Techniques. 2012.

[2] Y. A. M, W. Choiriah, and A. Akmal, "Penerapan Data Mining Menggunakan Metode Assiciation Rule dengan Algoritma Apriori untuk Analisa Pola Penjualan Barang," Jurteksi (Jurnal Teknol. dan Sist. Informasi), vol. V, no. 2, pp. 193-198, 2019, doi: https://doi.org/10.33330/jurteksi.v5i2.362.

[3] A. Setiawan and F. P. Putri, "Implementasi Algoritma Apriori untuk Rekomendasi Kombinasi Produk Penjualan," Ultim. (Jurnal Tek. Inform., vol. XII, no. 1, pp. 66-71, 2020, doi: https://doi.org/10.31937/ti.v12i1.1644.

[4] A. R. Riszky and M. Sadikin, "Data Mining Menggunakan Algoritma Apriori untuk Rekomendasi Produk bagi Pelanggan," J. Teknol. dan Sist. Komput., vol. 7, no. 3, pp. 103-108, 2019, doi: 10.14710/jtsiskom.7.3.2019.103-108.

[5] G. T. Napitupul, A. Oktaviani, D. Sarkawi, and I. Yulianti, "Penerapan Data Mining Terhadap Penjualan Pipa Pada Cv. Gaskindo Sentosa Menggunakan Metode Algoritma Apriori," J. Ris. Inform., vol. 1, no. 4, pp. 167-172, 2019, doi: 10.34288/jri.v1i4.96.

[6] J. L. Putra, M. Raharjo, T. A. A. Sandi, Ri. Ridwan, and R. Prasetyo, "Implementasi Algoritma Apriori Terhadap Data Penjualan,” J. Pilar Nusa Mandiri, vol. 15, no. 1, pp. 85-90, 2019, doi: https://doi.org/10.33480/pilar.v15i1.113.

[7] O. Pahlevi, A. Sugandi, and I. D. Sintawati, "Penerapan Algoritma Apriori Dalam Pengendalian Kualitas Produk," Sinkron, vol. 3, no. 1, pp. 272-278, 2018.

[8] A. M. A. Rahim, G. A. Suni, S. Sasi, G. C. Pangestu, M. Fainsenem, and M. A. A, "Implementasi Algoritma Apriori untuk Mengetahui Pola Pembelian di Starcomp Jogja," J. Ilm. Intech Informatioan Technol. J. UMUS, vol. 2, no. 01, pp. 61-70, 2020, doi: https://doi.org/10.46772/intech.v2i01.187. 
[9] D. Sepri and M. Afdal, "Analisa Dan Perbandingan Metode Algoritma Apriori Dan FpGrowth Untuk Mencari Pola Daerah Strategis Pengenalan Kampus Studi Kasus Di Stkip Adzkia Padang,” J. Sist. Inf. Kaputama, vol. 1, no. 1, 2017.

[10] A. G. Putri and R. M. H. Bhakti, "Penggunaan Certainty Factor Dalam Sistem Pakar Diagnosa Penyakit Jerawat," J. Ilm. Intech Informatioan Technol. J. UMUS, vol. 1, no. 02, pp. 86-96, 2020, doi: https://doi.org/10.46772/intech.v1i02.72.

[11] A. Premana, "RANCANG BANGUN SISTEM INFORMASI INVENTORY BARANG (SINBAR) BERBASIS WEBSITE," J. Ilm. Intech Informatioan Technol. J. UMUS, vol. 1, no. 02, pp. 51-61, 2019, doi: https://doi.org/10.46772/intech.v1i02.73.

[12] M. Fauzy, K. R. Saleh W, and I. Asror, "Penerapan Metode Association Rule Menggunakan Algoritma Apriori Pada Simulasi Prediksi Hujan Wilayah Kota Bandung," J. Ilm. Teknol. Inf. Terap., vol. II, no. 2, pp. 221-227, 2016, doi: https://doi.org/10.33197/jitter.vol2.iss3.2016.111.

[13] Kusrini and T. Emha, "Definisi Data Mining," Data Min., 2015.

[14] E. T. L. Kusrini, Data Mining Data mining. 2005.

[15] M. Afdal and M. Rosadi, "Penerapan Association Rule Mining Untuk Analisis Penempatan Tata Letak Buku Di Perpustakaan Menggunakan Algoritma Apriori," J. Ilm. Rekayasa dan Manaj. Sist. Inf., vol. 5, no. 1, p. 99, 2019, doi: 10.24014/rmsi.v5i1.7379.

[16] A. Setiawan and R. Mulyanti, "Market Basket Analysis dengan Algoritma Apriori pada Ecommerce Toko Busana Muslim Trendy," JUITA J. Inform., vol. 8, pp. 11-18, 2020, doi: 10.30595/juita.v8i1.4550. 